New forms of organisation and R\&D internationalisation among the world's 100 largest food and beverages multinationals

\author{
By \\ Fragkiskos Filippaios \\ Senior Research Fellow \\ Ministry of Economy and Finance \\ Hellenic Observatory, European Institute \\ London School of Economics and Political Science \\ Cowdray House (J203) \\ Houghton Street \\ London WC2A 2AE \\ United Kingdom \\ Tel: +44 (0) 2079557720 \\ Fax: +44 (0) 2079556497 \\ E-mail: F.Filippaios@1se.ac.uk \\ Marina Papanastassiou \\ Research Professor \\ Department of International Economics and Management-INT \\ Director \\ Center for International Business and Innovation- CIBI \\ Copenhagen Business School \\ Porcelænshaven 24, DK-2000 Frederiksberg, Denmark \\ Tel: +4538152538 \\ Fax: +4538152500 \\ E-mail: mp.int@cbs.dk \\ Robert Pearce \\ Professor of International Business \\ Dept of Economics \\ Reading University Business School \\ PO Box 218 \\ Whiteknights, Reading \\ RG6 6AA, United Kingdom \\ E-mail: r.d.pearce@ reading.ac.uk

\section{Ruth Rama (*)} \\ Research Professor \\ Department of Economics \\ (CSIC) Spanish National Research Council \\ c/Albasanz, 26-28 \\ 28037 Madrid, Spain \\ Tel: +34 916022402 \\ E-mail: $\underline{\text { rrama@ieg.csic.es }}$
}

(*) Corresponding author 


\title{
New forms of organisation and R\&D internationalisation among the world's 100 largest food and beverages multinationals
}

\begin{abstract}
This paper explores the strategic internationalisation of Research \& Development activities of the world's $100^{\text {th }}$ largest food and beverages multinationals in 1996 and 2000 with a sample of nearly 8,000 affiliates for each period. We focus on the overlying structures of R\&D control and management implemented by these companies. We approach the internationalisation process using a typology developed and expanded in earlier studies, and investigate the role of the $R \& D$ oriented subsidiaries according to the internal resources of the company as well as the mandate of the subsidiary. Our results show trends towards the centralisation of these activities in a few locations within the Triad. Moreover, these mechanisms of control are heavily centralised in home-countries, much more so than the rest of the multinational network. We find indications that the geographic patterns of these mechanisms differ from those of the traditional labs of the same firms which are much more decentralised. The propensity to implement technological affiliates seems to relate to the home-country and is especially evident in Japanese food and beverage multinationals. Highly internationalised firms need to organise their $R \& D$ activities through specialised affiliates which centralise and direct the innovative activities of the company. Firms less internationalised, however, would need to implement this type of arrangement when they are very innovative. A large size and great product diversification do not seem to especially induce firms to establish these mechanisms of R\&D control and management. Furthermore, the level of company's country spread is not a good predictor of the launching of technological affiliates specialising in product adaptation.
\end{abstract}

Keywords: Food \& Beverages, Multinational Enterprises, Research and Development, Foreign Affiliates 


\section{Introduction}

Innovation and technology are of particular importance to the development agenda of countries (UNCTAD 2005) and a relevant contributing factor, perhaps the most important, to the creation of competitive advantage for firms (Porter, 1998). Learning processes provide the foundations for establishing technological competencies or organisational capabilities that contribute to the firm's competitive advantage (Cantwell and Kosmopoulou 2001; Cohen and Levinthal 1989; Kuemmerle 1997, 1999; Pearce 1999). R\&D is, thus, a major determinant of good performance in global corporate competition for Multinational Enterprises (hereafter, MNEs) (Frankho 1989).

Given these developments, the internationalisation of R\&D has attracted the interest of both academics and practitioners as such strategies enable the firm to tap into knowledge externalities in world centres for scientific and technological excellence, and facilitate agreements with research institutions which are at the forefront of research.

However, there are still few empirical analyses on the MNE's new transversal structures. While general aspects of the internationalisation of $R \& D$ have now been thoroughly explored, our knowledge of these relatively recent $R \& D$ super-structures is still insufficient. There is a need to complement the traditional analyses based on patent data or foreign $R \& D$ expenditures with studies on these new forms of $R \& D$ organisation in MNEs, in order to understand better the internationalisation of these companies' innovative activities.

This paper analyses the global organisation of $R \& D$ in the leading firms of the food and beverages industry, and the motives that drive these firms concentrating their most relevant innovative resources in a few centres, often located abroad. In doing so, we analyse a sample of around 8,000 affiliates pertaining to the world's 100 largest food and beverage multinationals (hereafter, F\&B MNEs). We approach the internationalisation process using a typology developed and elaborated in earlier studies (Pearce 1999; Pearce and Papanastassiou 1999) and investigate the role of the R\&D oriented subsidiaries of MNEs according to the internal resources of the company and the mandate of the subsidiary.

The rationale supporting the use of an intra- firm based sample that describes and captures the dynamics of R\&D in a mature sector is easy to establish. First, most studies on these new forms of international $\mathrm{R} \& \mathrm{D}$ coordination focus on high-tech firms. To our knowledge, there are no analyses specifically centred on these structures in mature sectors. Therefore, our study contributes to the aim of sheding more light on innovation in the so called low -tech industries, as proposed by recent 
analyses (von Tunzelmann and Acha 2005). Second, the majority of previous studies on these forms of global R\&D organisation are case- studies of small groups of companies. These analyses, in our view, should be complemented with statistical analyses of large samples of similar companies. Aspects such as the extent of these new networks and the geography of R\&D control in an international industry, or even trends towards spatial centralisation or decentralisation, cannot be generalised from the analysis of small groups of firms and need to be tackled with representative samples of companies, such as the one used here. On the other hand, we argue, the geographic patterns of these new centres are not necessarily the same as the geographical patterns depicted by analyses based on patents and R\&D expenditures, which are more likely to reflect the spatial distribution of traditional labs attached to production units. Hence, the interest of contrasting the results of these traditional studies on the internationalisation of $R \& D$ with statistical analyses of specialised centres in the same international industry. These comparisons also require representative samples of similar companies. Third, although Food \& Beverages (F\&B) sector is classified as a low R\&D intensity sector (UNCTAD 2005), F\&B MNEs internationalise their R\&D activities, according to patent analyses, more than MNEs in other sectors do (Alfranca et al. 2005; Cantwell and Hodson 1991). Furthermore, F\&B MNEs should be considered as precursor to other

MNEs because they are, on average, older and more internationally experienced and more internationalised (Stopford and Dunning 1983). Their analysis, therefore, could help towards a better understanding of the rationale for the new patterns of $R \& D$ internationalisation in other MNEs.

The rest of the paper is organised as follows: The next section provides the theoretical foundations. Section three contains the literature review, section four presents the data and sample description, whilst section five discusses our empirical methodology and variables. The empirical results and their interpretation are discussed in section six. Finally, section seven concludes the paper by offering future research questions.

\section{Theoretical Background}

From its initiation, realistic analysis of the MNE has found a key role for innovation and technology transfer. One of the most significant journeys in our understanding of international business has been that from an essentially centralized view of innovation in MNEs towards one that encompasses an increasing range of decentralized inputs and strategic postures (Pearce and Papanastassiou, 2006). Vernon's (1966) pioneering Product Cycle Model (PCM) showed, in effect, how US firms 
became MNEs by using abroad (through technology transfer) competitive advantages generated (through innovation) in their home country for products moving from the innovative to growth stage of their product cycle. However, one of the most important changes in MNE strategy over the past 40 years has been a movement away from home country innovation towards a much more decentralized approach to creation of new technology and product innovation.

"The external change that we see as conditioning the need for new approaches to innovation in MNEs is that, through most of the last third of the 20th Century, the spread of sustained economic growth led to an increased number of countries at quite similar and high levels of income. Taken with increased numbers of firms competing internationally and the shortening of product life cycles this meant that, even if the essence of a new innovation emerged in one location, firms would need to get the new good into all key markets with the greatest possible speed. Internal to the firm, once it has been through the PCM the assumption that it is not an MNE has been removed and this alters its organisational structure in a way that, in effect, provides it with the mechanism to deal with the new competitive need provoked by the external change. Indeed it would be an expectation of internal competition in MNEs that ambitious subsidiaries in major markets would demand early access to important new products emerging elsewhere. This would, in some ways, collapse the first two stages of the original PCM into one internationally-differentiated innovation process" (Papanastassiou and Pearce, 2007, p. 3). Firms, thus, are increasingly aware of a need to respond to different tastes and market characteristics throughout the global economy and similarly of different potentials to learn and create new technologies in different national systems of innovations (NSIs).

These perspectives can be schematically formalized as a global innovation strategy (GIS) of MNEs fulfilling three key aims: Firstly, to detect and internalize new creative potentials from diverse sources of science and technology; secondly, to derive from these the broad parameters of a new product concept (NPC); thirdly, to complete the competitive development of the NPC in different forms that correspond to markets with different tastes and at different levels of development.

From an implementation perspective, this GIS is being overseen and coordinated by a central research and development (R\&D) laboratory and operationalized through three types of decentralized and networked laboratories. The first of these lab types is the internationally interdependent laboratory (IIL), which carries out basic/pre competitive research by tapping into and internalizing distinctive strands of its host- location scientific agendas and technological 
capabilities. Assembling a network of IILs, each accessing different local scientific potentials, i.e. responding to technological heterogeneity, provides an MNE with a range of complementary sources of new knowledge. By encouraging knowledge exchanges between IILs, and by itself seeking to understand and assimilate research output from throughout the network, the central lab aims to ultimately assemble the technological basis of a strong NPC. The preceding point leads us to the coordinating role of a 'parent' laboratory in a GIS, and indeed of the status of a home-country parent HQ in an MNE which is now placing significant emphasis on the decentralization of much of its creative and innovative strategic activity.

Once the basis of the NPC are in place, the second type of decentralized laboratory, the locally integrated laboratory (LIL), comes into play. Working with a product mandate (PM) subsidiary the LIL operationalizes the new technology in collaboration with other local creative functions, especially marketing and engineering. Thus, a network of LILs allows the MNE to develop a range of differentiated variants of the new good so as to meet the specific needs of particular market spaces (i.e. respond to market heterogeneity). An LIL is a central element in the PM's creativity, and essentially mediates new science emerging from applied research to the other functions (i.e. those with which it works in a closely integrated fashion) involved in the innovation process. In a fully-developed GIS an MNE will authorize a separate PM/LIL nexus in each of several regional markets to generate a distinctive variant of the NPC that responds to all the idiosyncratic tastes and needs of its regional customer base and optimizes the production technology in its use of the input environment (availability and price of factors) of the host country. A subsidiary operating in this manner can be designated as having a regional product mandate (RPM) (Papanastassiou and Pearce, 2007).

Though the work done by IILs and LILs, as mediated and motivated by the central lab, completes the innovation process per se, a third type of decentralized lab remains to play a further role in MNE group competitiveness. Thus, once the new product is successfully introduced to a new market the basis of its competitiveness will gradually move from its originality towards more price/cost related factors. At this point supply may need to be relocated to low- cost production sites that have no prior experience of the good or its technology. The extensive technology transfer involved in this generation of cost- effective supply networks is supported by support laboratories (SLs). These technology transfer labs can have two variants. SL1s, we consider, are located in recipient efficiency- seeking subsidiaries and aim to assimilate and operationalise the technologies (i.e. inward technology transfers). By contrast SL2s will be located 
in subsidiaries already using the technology and teach it (i.e. outward technology transfer) to its new users. This efficiency-seeking behaviour takes us back into the world of hierarchy and technology transfer.

Overall, within an MNE's global innovation and competitiveness strategies these types of labs secure access to new technology, its operationalisation in new goods and the prolonged competitiveness of these goods in globalized markets.

\section{Literature review}

At the beginning of the 1990s, Patel and Pavitt (1991) still cast doubt on the globalisation of $\mathrm{R} \& \mathrm{D}$ activities and demonstrated, after examining their patents, that most of the innovative activities of the world's largest firms were performed in the home country. More recent research has assessed, however, clear trends towards internationalisation of R\&D; MNEs, especially those of small European countries, have increased their foreign R\&D activities (Le Bas and Sierra 2002; OECD 2005). Some authors have noted, nevertheless, the limits of the phenomenon, claiming that it is an intra-Triad or even a regional phenomenon (especially in the EU), rather than a global one (Archibugi and Michie 1995). Also, it has been claimed that the most important R\&D functions of MNEs are carried out in the home country, though evidence has not yet been provided (Hu 1992).

A large number of analyses based on patent databases or R\&D expenditures have broadened our empirical knowledge of this phenomenon (Blanc and Sierra 1999; Cantwell and Kosmopoulou 2001; Granstrand et al. 1993; Hakanson and Nobel 1993; Kuemmerle 1997, 1999; Le Bas and Sierra 2002; Pearce and Papanastassiou 1999; UNCTAD 2005; Wortmann 1990). With few exceptions, these studies are concerned with the economics of the internationalisation of R\&D and associated policy issues, rather than with organisational aspects.

In the last period, however, overlaying structures that coordinate learning and corporatewide R\&D activities within the MNE have become increasingly important. (Gassmann and von Zedtwitz 1998; Gerybadze and Reger 1999; Reger 2004). As described in the GIS model a few specialised centres tend to control $R \& D$ developed in multiple, geographically dispersed, laboratories often linked to production units. As cooperation becomes more widespread, companies need to coordinate research that is outsourced in smaller, specialised firms or in Universities. These overlaying structures may consist of specialized affiliates whose specific mandate is in the innovation and technology field (as opposed to the production field). They could be in charge of 
long-term knowledge creation, while dispersed labs could specialise in transforming new ideas into marketable products in the short term (von Zedtwitz et al. 2004). According to some authors, these new mechanisms and forms of organisation are now driving forces for the internationalisation of R\&D (Gerybadze and Reger 1999). Though these centres are not yet numerous, they perform key functions concerning R\&D coordination, management and control within the multinational network. As noted by Manolopoulos et al. (2005, p.2), "there are many cases of subsidiaries that perform specific value -added activities, which are fundamentally 'embedded' in their respective host- countries knowledge systems".

As stated, transcending from the hierarchical mode of operation that was depicted in Vernon's PCM towards a model of GIS requires some of the affiliates of MNEs to have a specific mandate in the technological and R\&D field. Extensive work by Pearce (1995), Taggart and Hood (1999), Hood, Young and Lal (1994), Young, Hood and Dunlop (1988), Birkinshaw and Morrison (1996) and Birkinshaw and Hood (2000) has provided a solid theoretical and applied framework for the understanding of the MNE group as a network of subsidiaries with evolving strategic priorities and roles.

“Thus we can now see a 'centre' as no longer generating all the key competitive competences and taking full responsibility for the planning of their use throughout the group. Instead, in this more heterarchical (Hedlund, 1986, 1993; Birkinshaw, 1994) context, it is the HQ that aspires to the fullest understanding of what is evolving in dispersed operations and, from this, of securing an effective balance in networks of both supply and creative units" (Pearce and Papanastassiou, 2006) ( see also Papanastassiou and Pearce, 1999; Pearce, 1999; Christensen 1998; G.E.S.T. 1986; Gassmann and von Zedtwitz 1998; Gerybadze and Reger 1999; Reger 2004). From a different perspective, Pavitt (1992) also insists on the importance of corporate-wide coordination to promote technological synergy across divisions. Some authors observe a distribution of labour between overlaying structures, which could either be in charge of research, or instead dispersed labs attached to business units, which perform development (von Zedtwitzet al. 2004). Links between the company and Universities (an element of the host-country's NSI) are sometimes coordinated at the global level (Lam 2003).

As indicated in the introduction to this paper, F\&B MNEs are more internationalised in terms of their foreign to total affiliates ratio, their foreign to total sales ratio, their country scope and their R\&D, than other MNEs (Anastassopoulos and Rama 2005; Cantwell and Janne 2000; Ietto- 
Gillies 2002). Patent analysis for the 1969-1994 period indicates that the world's largest F\&B MNEs perform nearly 30\% of their innovative activities abroad (Alfrancaet al. 2005). In F\&B MNEs, the level of internationalisation of the R\&D activities could vary by home country of the company. For instance, a study calculates that US-based companies in this industry internationalise $10 \%$ of the innovative activity; companies from The Netherlands, a small European country, by contrast internationalise $87 \%$ (Alfrancaet al. 2005). On the other hand, following the institutional approach to organisational forms, it has been argued that the behaviour of foreign labs could vary by home country of the company (Lam 2003). A reason for these strategies is that proximity to the foreign market is crucial for $\mathrm{F} \& \mathrm{~B}$ MNEs as they are required to be highly locally responsive (Bartlett \& Ghoshal, 1986). Therefore, they often serve foreign markets by foreign production rather than by exports (Pearce 1993).

The top 100 F\&B MNEs (hereafter, the Top 100) account for one third of production (Rastoin et al. 1998) and more than one half of the technological activities of the world's food and beverage industry (Alfranca et al. 2002).

For these firms the adoption of a model of GIS, through the creation of new products and adaptation of their products to local tastes and, therefore local $R \& D$, are necessary because, in spite of recent trends towards homogenisation of diets in the West (Connor 1994; Schmidhuber and Traill 2006), food consumption remains culturally bound. In this international industry, the underlying R\&D network has been built, to a large extent, on an ad hoc form, following the M\&A operations and the needs of manufacturing (Tozanli 2005; von Zedtwitzet al. 2004), rather than those of research. The Top 100 are competent in a variety of technological fields in addition to food technology, and also patent in agriculture, biotechnology, chemicals, drugs, etc. (von Tunzelmann 1998). In-house research plays a substantial role, though R\&D collaboration is not uncommon. Dedicated biotechnology firms, however, play a negligible role in food science; in some of the most important biotech fields for Europe, for instance, most $R \& D$ is between a small group of $F \& B$ MNEs and one or several public research institutions (Senker and Mangematin 2007 ). In some of their most profitable markets (i.e. nutraceuticals) large food and drink firms now face competition from pharmaceutical firms and their labs (Wilkinson 2002). According to patent analyses, technological competition is also substantial within the international agro-food sector (Alfranca et al. 2003). 
In sum, the great country spread of F\&B MNEs and the importance of their innovative activities suggest that these firms genuinely adopt a model of GIS and require specific structures to manage their R\&D on a global basis.

The integration of different types of technical capabilities is a major objective for $F \& B$ MNEs since these firms now develop a broad spectrum of techniques and scientific knowledge (e.g. life sciences, software, instrumentation) to produce their foodstuffs and interact fruitfully with their suppliers of equipment and inputs (von Tunzelmann 1998). In a study on 90 very large food MNEs Alfranca et al (2004a) found that firms which hold a high proportion of technological affiliates (hereafter, TA) are likely to assimilate better their technological capabilities in fields such as food proper, chemicals, biotechnology and drugs. The geographical patterns of TAs could also vary because this type of FDI could follow the general geographical pattern of FDI in the company, which vary, in turn, following the origin of capital (Ietto-Gillies 2002).

When, by contrast, R\&D is exclusively performed and distributed at the division level (SL2 type of laboratory) or is outsourced to external suppliers, Christensen (1998) argues, the integration of technological capabilities within the company could be less complete. In short, a corporate centre of strategic technology management could be "a vital vehicle in promoting a coherent technology base "from above"" (Christensen 1998, p.34).

\section{Sample Description}

Our sample of F\&B MNEs comprises 81 companies taken from the Top 100, with nearly 8,000 affiliates. Continuing firms included in this group in 1996 and 2000 were selected for this study, a method which enabled us to analyse changes taking place during this period. The list of firms comes from the AGRODATA database (IAMM 1990; Padilla et al. 1983; Rastoin and Tozanli 1998). The main sources for compiling the AGRODATA database are Moody's Industrial Manual, the Fortune 500 directory, the "Dossier 5000" published by Le Nouvel Economiste and the annual reports of the firms ${ }^{1}$ ). This is the most comprehensive information available on the activities and location of the affiliates of the world's largest F\&B MNEs, though it has yet been seldom exploited in studies published in English. F\&B MNEs included in the database have worldwide agro-food sales

1 In English, Tozanli (2005) provide tables containing some of these data. Information on the IAMM and AGRODATA (in French) is available in the following web page: http://www.iamm.fr/default.htm. 
amounting to a minimum of US\$ $1 \mathrm{bn}$. per year and at least one food-processing plant outside the homecountry (Rastoin et al. 1998). This database includes world renowned firms such as: Coca Cola Co., Danone, General Mills, Heinz, Nestle, PepsiCo, and Unilever. A key advantage of our sample is that it includes MNEs originating from multiple home countries and most of the firms are active in a number of different food \& beverage sectors, such as: meat processing, dairy products, confectionary, spirits, and so forth. In short, different home-countries and sub-sectors are well represented.

In our database, company level information includes: country spread, i.e. the number of foreign countries where the company operates through an affiliate, size as measured by the total sales and net income in US\$.

For 2000, we analysed unpublished information on 7,168 affiliates ${ }^{2}$ provided by AGRODATA; for 1996, we processed and analyzed data on 6,330 affiliates published by the same source (Rastoin et al. 1998). Affiliate level information includes: name of the affiliate; name of the parent; home-country of the company; host-country, host-region and economic activity as defined by the UN-International Standard Industrial Classification (ISIC) code. We supplement the AGRODATA source of information with the analysis of company documents, web pages and case studies.

\section{Statistical Methodology and Variables}

In this paper our main objective is the analysis of technological affiliates (TAs) within the structure of a multinational network; the target variable, therefore, is the average number of TAs per firm. We selected affiliates with two characteristics: 1) they have a specific mandate in the innovation and technology field, and 2) they are hierarchically independent from production units of the company (see Appendix 1). These TAs correspond to a portfolio of IILs, LILs and SLs described previously, which is the integrating component of the GIS. Thus, by TAs we group the different types of R\&D laboratories described in the theoretical background section. This grouping allows us to distinguish between the creative units and the production units within the MNE

\footnotetext{
2 Affiliates are establishments where the parent holds at least $5 \%$ of the equity share capital.. In our sample, the parent controls, on average, $70 \%$ or more of the share capital in $90 \%$ of the affiliates.
} 
network In this study we specifically analyse the geographical patterns of different groups of TAs, by home region of the parent.

AGRODATA classifies all the affiliates of the Top 100 by their main activity, following the United Nations Standard Industrial Classification (UN-SIC) code. This enables us to identify the TAs pertaining to the sampled companies and the main function (e.g. basic research) performed by such centres.

In our sample, $43 \%$ of the companies own at least one of these specialised affiliates. This result suggests that, even in a mature sector, a substantial number of the companies already manage their global R\&D through TAs. Though the first to implement these methods of coordination were high-tech companies (Gerybadze and Reger 1999), our results suggest that this form of R\&D organisation could now have been adopted by many MNEs which operate in traditional industries. The rest of the F\&B MNEs, however, may be using, if any, informal methods of control and coordination of $R \& D$, such as gatherings of project leaders or international mobility of scientists and technicians. However, this question could not be analysed with the available information. As will be seen below, these companies are likely to display limited country spread and innovative activity.

We used a Classification and Regression (C\&R) Trees Method (Breiman, Friedman, Olshen and Stone, 1984) to generate a binary decision tree, which was constructed by splitting subsets of the data set using predicting variables stemming from our theoretical conceptualization and the relevant literature. In $\mathrm{C} \& \mathrm{R}$ models the best predictor is chosen using a variety of diversity measures. The aim of the analysis is to produce subsets of the data which are as homogeneous as possible regarding the target variable, i.e. number of TAs. For each split, each predictor is evaluated to find the best cut point. Then the predictors are compared and the one with the best improvement is selected. For a complete list of variables used in the analysis and their description please see Table 1 .

\section{Insert Table 1 here.}

In what follows, we present the predictor variables. We measure innovation by using patent data (Archibugi and Pianta 1992, for the advantages and drawbacks of patent analyses, see ; Rosenberg 1982). The patents considered here include a variety of technological fields such as food 
proper, biotechnology, tobacco and also innovations related to non-core businesses of the companies. These patents were produced by the whole company, not just by TAs. We took the relative frequencies of patents granted by company over 1977-94 from (Alfranca et al. 2004b), who use a similar database of food MNEs. Their source for patent data was USPTO, the US Patent and Trademark Office. In the literature of the economics of technological change patent data are often used in an aggregated form, including long periods of time, because the results of innovative efforts cannot be measured on year- by- year basis.

The available information contains data on utility patents for each sampled company. Here they protect property rights related to products or industrial processes. A large number of utility patents (UTPAT) could signal intensive R\&D activities within the multinational network. Given that the coordination of many innovative activities is a complex activity in a fully- developed GIS model, it is likely that strong patentors tend to use the TA form in order to coordinate them across divisions. We, thus, check the association of UTPAT with TA.

As stated, previous research on large food MNEs suggests that the ownership of TAs can be related to the development of generic technology which can be applicable to different lines of business within the company (Alfrancaet al. 2004a; G.E.S.T. 1986). An example of generic technology is biotechnology, which could be used in the production of different foodstuffs, nutraceuticals, feeds for animals, drugs, etc. Thus we check if a large number of TAs is associated with the company's unrelated diversification into non-food products. We use two different metrics to measure diversification: DIV, the company's non-food sales to total sales and ANC, a scope measure, which relates the number of affiliates involved in production of non-food products to the total number of affiliates owned by the company. This last measure of diversification is obtained from the information provided by AGRODATA on the UN-SIC codes of affiliates. If a company is heavily diversified into non-core products, it is more likely to carry out different types of R\&D (food and non-food). Thus, it should tap into different countries' NSI in order to capitalise on the heterogeneity of scientific expertise. This situation requires the coordinating role of a 'parent' or other 'central' laboratory.

Previous literature shows that F\&B MNEs based in some specific home countries, i.e. home countries exhibiting astrong science base as well as consumer awareness, are more prone to manage R\&D by implementing TAs. An empirical study based on 1988 data actually found that Japanese F\&B MNEs were more prone than other F\&B MNEs to coordinate their R\&D activities around TAs 
(Rama 1996). Thus, we test whether the home country (HCOUNTRY) is associated with a substantial presence of TAs within the MNE.

A large country spread (NCOUNT) could introduce complexity in the multinational network. According to the literature, large firms use their TAs to coordinate innovative activities performed in a variety of divisions. Thus, we check the association of NCOUNT and TA. NCOUNT also captures the dynamic developments in the external environment, as analysed in the theoretical part, whilst here it is also associated with the emergence of countries that have the knowledge capabilities to feed the innovative process of MNEs on a global basis.

As an alternative measure of the complexity of the multinational network and the degree of internationalisation of the company, we use a variable measuring the proportion of foreign affiliates to total number of affiliates (FATOT). In a similar fashion to NCOUNT, the variable FATOT underlines the realistic response of $\mathrm{F} \& \mathrm{~B}$ MNEs to tap into the productive and creative potential of their respective host countries.

In a study on 24 diversified companies, Coombs and Richards (1993) find that large firms tend to launch independent technological units decoupled from manufacturing establishments to ensure the diffusion of technological capabilities in a specific business within the whole corporation. Therefore, we also control for the size of the company as measured by global sales (SAL) since larger companies could tend to hold a larger number of TAs. An alternative measure of the size comes from the total number of subsidiaries (ATOT), a variable which also contributes to measuring the complexity of the multinational network. The more affiliates, the more complex the task to diffuse new innovation within the company; hence, the company will need to hold more TAs.

Finally we use two variables to capture the resources available to the company for launching a TA. Performance (PERF), as measured by net margins, could signal the success of the company (many strategic decisions are often made on the basis of short term financial results), whilst net income (NIC) proxies the total volume of human and financial resources available to the company.

\section{Results and Interpretation}

\subsection{Geographic patterns of TAs}


As already indicated we firstly explore the different geographic patterns of TAs. In Figures 1 and 2 we map them in 1996 and 2000 and find, for both years, an evident clustering of these specialised subsidiaries in the US, Japan and a few European countries; i.e. in regions that exhibit strong and diversified NSIs. This finding corroborates the results of a previous analysis based on a similar 1988 sample of F\&B MNEs (Rama 1996). The maps also confirm results found for MNEs in high-tech sectors in that these types of super structures tend to be concentrated in a few locations within the Triad. They also show that the number of developing countries hosting TAs decreased from 1996 to 2000; as will be seen below, moreover, the few developing countries that still hosted TAs at the end of the period saw a decrease of their share. This result suggests that MNEs may be responsive to distinct consumer tastes and also acknowledge the specialised inputs of certain developing countries, as noted by previous studies (Reddy 2000). Nevertheless the technological gap between the Triad and the rest of the world tends to favour locating MNE R\&D in the Triad.

\section{Insert Figures 1 and 2 here.}

Table 2 presents the percentage of TAs according to the home country of the mother company. Most of these specialised affiliates pertained, both in 1996 and 2000, to Japanese F\&B MNEs, a result which confirms a previous study based on 1988 data (Rama 1996). Some peculiarities of the Japanese F\&B MNEs could provide possible explanations. First, as noted by Reger (2004), the greater is the distance between cultures, the more the firm needs formal mechanisms of R\&D control (as opposed to informal mechanisms based on values and behaviour). Japanese F\&B MNEs often operate in markets where cultural distance is substantial for them (Filippaios and Rama 2006) and many of these production sites, such as the USA, display relevant innovative activity (Florida 1997). Second, in a study based on a similar sample of F\&B MNEs, Japanese F\&B MNEs have the largest share of non-food patents (e.g. biotech, chemicals, drugs) to total patents (von Tunzelmann 1998). In short, Japanese F\&B MNEs could need, more than other F\&B MNEs, to implement super structures of R\&D management to efficiently coordinate the work of scientists and technicians coming from very different cultures and disciplines.

\section{Insert Table 2 here.}


Between the two time periods, though, there is a significant restructuring, with a reduction in the Japanese-owned TAs and a respective increase in the Italian and Swiss-owned TAs. Results for the latter are influenced by the presence of two very large companies, Nestlé and Novartis, each holding a large number of TAs. The case of Novartis clearly illustrates the functions and geographic distribution of TAs within a large company, as well as the current role of life sciences among the global research objectives of F\&B MNEs. Formed in 1996 from a merger of Sandoz and Ciba Geigy, Novartis became at the time the world's largest agrochemical company and the second largest seed company (Chataway 2001); it also markets agro-food products such as baby food, nutraceuticals and diet drinks. Dedicated to a multiplicity of R\&D tasks, most of its TAs locate in the home-country (9) and the USA (12). It also owns TAs specializing in R\&D for seed production in, among other locations, Brazil, Honduras, Korea, France (2 affiliates), Japan, Italy, Mexico, Sweden, the Netherlands and the UK; other of its TAs around the world have been given responsibilities in, respectively, the R\&D of diet and health products, veterinarian products, etc. Novartis Institutes for Bio Medical Research are located in major global biotechnology hubs and are coordinated from Basel and Cambridge (UK).

Finally, confirming the results of a previous study based on 1988 data (Rama 1996), Britishowned TAs are also well represented among the total number of these specialised affiliates both in 1996 and 2000.

As shown by Table 3, the location of TAs is strongly concentrated in a few countries, notably in the US, showing a significant increase between the two periods. This result is coherent with previous findings of patent analysis showing that the US was the world's most important producer of food and food-related innovation, well ahead of Western Europe and Japan, in 1969-1994 (Christensen et al. 1996). Location of TAs in the subsequent 1996-2000 period probably reflects the geographic preference of F\&B MNEs for world centres of excellence in food science. This result agrees with the propositions analysed in the theoretical sections which underlines the interdependence between the model of GIS and NSI. By contrast, the share of TAs located not only in Brazil and the Philippines but also in some developed countries, such as France or Canada, fell over the period. This clearly reveals a tendency to centralisation, rather than decentralisation, of R\&D super-structures, a result confirming with a large sample those of some case studies for small groups of MNEs operating in high-tech industries (Gerybadze and Reger 1999; von Zedtwitzet al. 2004).

Table 3 also reveals the volatility of the location of TAs between 1996 and 2000. 


\section{Insert Table 3 here.}

Although at first sight the aggregate picture seems to be similar in 1996 and 2000, when one disaggregates the two points in time there are 89 changes over the period. Those changes are related either to disinvestments, new investments or changes in the subsidiaries' roles (see Birkinshaw, 1996). As suggested by previous research (G.E.S.T. 1986), some TAs could be transitory forms of organisation. A study on MNEs in high-tech sectors notes, for instance, that independent labs that do not bear fruits as expected by the parent could lose their status and be reintegrated within other structures of the company (Lam 2003).

\section{Insert Table 4 here.}

When compared with the rest of F\&B MNEs activities ${ }^{3}$, R\&D control activities seem to have the smallest proportion of operations abroad in both years (Table 4). Moreover, while the average internationalisation of the companies increased as well as that of each of the individual categories of affiliates (e.g. food manufacturing units), TAs became, by contrast, less internationalised during the period. This result confirms our previous arguments regarding the need for specialised inputs among the host locations as well as the need for rationalisation towards more efficiency-seeking behaviour. Table 5 takes this discussion a step further and examines the centralisation versus decentralisation argument through a regional perspective.

\section{Insert Table 5 here.}

For Asian F\&B MNEs (all Japanese in our sample), between 70-75\% of their TAs were located in Asia during 1996-2000. A possible explanation of these MNEs' behaviour is that their other facilities, notably their manufacturing units, also strongly concentrate in Asia (Anastassopoulos and Rama 2005). Second, a study on high-tech companies suggests that Japanese MNEs could be constrained by their home-base institutions to tap into dispersed scientific labour pools (Lam 2003). This circumstance could be an additional motive for Japanese F\&B MNEs keeping their most valuable R\&D centres in the home country or close to it.

\footnotetext{
${ }^{3}$ A complete description of activities can be found in Appendix 1.
} 
At the beginning of the period, however, the most centralised F\&B MNEs were those based in the European Union, though the share of their regional TAs fell from $90 \%$ to $72 \%$ of the total over the period. Most of the rest locate in North America. As for their European TAs, they are often geographically disseminated, with a specialisation by host country. For instance, Nutreco, a Dutch F\&B MNE, is vertically integrated in animal feed, nutritional additives, fish feeding, aviculture, poultry ingredients, aquaculture and meat processing. It has three TAs in the home country in, respectively, research in swine and ruminants, and in breeding; other TAs have been given responsibilities in poultry research (Spain) and aquaculture research (Norway and Japan). This result strongly confirms our postulations on MNEs acknowledging scientific diversification and thus tapping into the distinctive parts of the host-country's NSI.

Our results contrast with those of previous research on the internationalisation of $R \& D$, based on patent data, since these studies suggest that European F\&B MNEs perform the bulk of innovations abroad, even in extra-regional locations. EU- based F\&B MNEs performed nearly $83 \%$ of their innovative activities abroad in 1969-1994 (Alfrancaet al. 2005). According to another study, European-owned firms patented $77.2 \%$ of their innovations abroad in the United States and only 22.1\% in Europe in 1991-1995 (Cantwell and Janne 1999, 2000). A possible explanation is that they perform such a large portion of their R\&D in the US to support local manufacturing (the US is one of their most important markets) and to access local technology; also, they may seek to monitor the R\&D strategies of American F\&B MNEs, which are their most important competitors in European markets. Finally, some F\&B MNEs find that they can benefit from access to two different scientific cultures, the American and the European, and that accommodating two different systems of regulation concerning crops, food or the environment could stimulate their own creativity (Chataway 2001). As shown by our results, by contrast, they prefer to control global R\&D from European locations.

Our finding regarding the TAs of European companies contributes a new perspective to the policy debate, which has been concerned with extra-territoriality of $R \& D$ of these firms in all sectors, and more specifically, in agro-food (Bijman et al. 1997; Doz 2005; Erken and Gilsing 2005; Sachwald 2005). Our results show, by contrast, that important R\&D structures actually remain in the home region.

Finally, supporting Gerybadze and Reger's (1999) results, we also find here that the MNEs' geographical patterns of innovation and of $R \& D$ control and coordination could differ. In these authors' view, discrepancy between general trends of R\&D internationalisation and TAs points to a 
first wave of "transnational innovators" followed by an attempt of the MNE towards increased coherence and efficiency.

By contrast, North American F\&B MNEs seem to adopt a more integrated GIS concerning TAs than Japanese or European F\&B MNEs, though they still keep most of these specialised centres in the home region. As stated, according to patent analysis for 1969-1994, US F\&B MNEs produce abroad only $10 \%$ of their patented innovations; in other words, their R\&D activities are highly concentrated in the home country (Alfrancaet al. 2005), which offers important sources of technological know-how in this specific field. Their global R\&D management and coordination facilities are, however, relatively more decentralised, following some of their most important markets in the EU and Asia.

As a first step towards the analysis of global R\&D management in the international agro-food industry, this article, however, focuses specifically on the internal determinants of TAs. We turn to this question next.

\subsection{Internal predictors of TAs structures}

In order to identify the internal determinants of the existence of a TA we employed a CHAID (Chi-Square Automatic Interaction Detection) to generate a decision tree. Our key variable under investigation in this step is the average number of TAs by company. The predictor variables are those in Table 1. In our model, risk was 4.9, which means that the model did not classify correctly only $4.9 \%$ of the sample. The model is presented in Figure 3.

\section{Insert Figure 3 here.}

Our data show that the most important reason determining the presence of a large number of TAs is the country spread of the MNE, confirming the application of a GIS model versus a more hierarchical and centralised technology generating structure. In other words, highly internationalised firms need to organise their R\&D activities through specialised affiliates which organise and direct the innovative activities of the company. The best predictor for TA is NCOUNT, a variable denoting the country spread of the MNE. The average number of TAs per firm is 1.2284 in our sample. While firms that have spread to 40 or fewer countries have, on average, only 0.8849 TAs, those that have spread to more than 40 countries have 3.3043 . This cut- 
point was calculated as the Mean (21 countries) plus the Standard Deviation of the NCOUNT variable (19).

Among the firms that have spread to fewer countries, a large number of TAs are associated with intense patenting activity. The companies accounting for $0.340 \%$ or less of the utility patents granted to the sampled companies have, on average, only 0.4848 TAs. By contrast, the companies accounting for more than $0.340 \%$ of the utility patents have 1.8750 TAs. Following analyses of variance methods, this cut-point maximizes differences on the dependent variable between the two nodes.

To study further the association between number of TAs and country spread and understand the deployment of a GIS, we split the sub sample of the highly internationalised companies between two subsets: companies that had spread to 40-59 countries and companies that had spread to more than 59 countries. In order to take full account of the statistical distribution of the country spread variable, this second cut-point (59 countries) was calculated as the Mean plus two Standard Deviations of the NCOUNT variable. As shown by the tree, the improvement of the model was substantial. The most internationalised companies have nearly four times more technological affiliates than the companies spreading to 40-59 countries and around six times more technological affiliates than the average F\&B MNE. Differences are statistically significant. This indicates that highly internationalised F\&B MNEs operate around a genuine network structure where they employ their subsidiaries to tap into the host -environment knowledge and skill resources (Almeida et al, 2002; Cantwell and Janne, 1999)

Strong patentors, even if they spread to relatively fewer countries, have more TAs than firms spreading to 40-59 countries, whatever their level of innovativeness. However, such strong patentors which spread to fewer countries have fewer technological affiliates than the most internationalised firms in our sample (NCOUNT > 59). This means that the variable more closely associated to TA is NCOUNT. In other words, highly internationalised firms need to organise their R\&D activities though specialised affiliates which centralise and direct the innovative activities of the company. However, firms that are less internationalised could still need to implement this type of arrangement when they are very innovative.

As already indicated in the theoretical background section, in order to capture the distinction among the various types of TAs, and to further analyse the relationship between the level of internationalisation of the company and the number of its technological affiliates, the root node (TA) is split to form two new nodes. The first includes the technological affiliates involved in 
product adaptation (ADAPT). These include the SL1 and SL2 types of laboratories. The second then comprises the rest of the technological affiliates, which are devoted more creative forms of technological activity, e.g. basic research, etc. (OTHERTECH) which include the IIL and LIL types of laboratories. This distinction expands further the argumentation between the choice of a centralised versus a decentralised approach, and it actually demonstrates that a fully- developed GIS model contains both elements via the qualitative difference of its TAs. So it is crucial to understand that the discussion around centralisation and decentralisation becomes less clear cut once we acknowledge that these are the two components of a GIS.

Now we develop a new tree (See Figure 4), where the right node accounts for the ADAPT affiliates and the left node for the OTHERTECH affiliates.

\section{Insert Figure 4 here}

As shown by Figure 4, NCOUNT is a good predictor for OTHERTECH. Companies which spread to 46 or fewer countries have, on average, only 0.6544 OTHERTECH affiliates, while companies which spread to more than 46 countries have, on average, 4.6154; differences are statistically significant. Following analyses of variance methods, this cut-point maximizes differences between the two groups of firms. By contrast, we find that NCOUNT is not a good predictor for ADAPT. In this case, the difference on the dependent variable between companies with different levels of country spread is not statistically significant. The tree could not be developed further, however, owing to the small size of the sub-samples. This result confirms our argument around the two different components of a GIS model, i.e. a dynamic one which is related with more high value-added knowledge activities which are carried out by IILs and LILs a static one which is less ambitious and is carried out by SL1s and SL2s.

In short, this mode of organisation of the $R \& D$ activities seems to be related to the complexity of $R \& D$ within the firm, either because $R \& D$ is disseminated in laboratories attached to centres located in many countries or because the laboratories themselves are highly innovative (even if they are located in a few countries). Finally, the level of a company's country spread is not a good predictor of the launching of TAs specializing in product adaptation. A better one could be the number of cultural areas, rather than the number of countries, to which the company has spread, since the MNE, probably, needs to adapt its foodstuffs following its expansion across food cultures. 


\section{Conclusions and Future Research}

In this paper we developed a model of global innovation strategy (GIS) where two components of a dynamic one, i.e. a genuine centrifugal force and a static one, i.e. a centripetal force, coexist and determine the degree of internationalisation within MNEs. We argued that in a fully developed GIS model the sourcing of creative inputs does not come exclusively from a 'central' R\&D laboratory, but also other overseas laboratories that undertake genuine knowledge creation activity capitalising on the scientific heterogeneity fostered in individual host countries NSIs. In this case the 'central' lab plays a more coordinating role. Nevertheless, we acknowledged that new knowledge creation is associated with new product concepts which do not remain always new but through their life cycle can become more mature and standardised. This trend is reflected also in a GIS model with the adoption of a more efficiency-seeking activity of overseas R\&D labs which results in a more hierarchical organisational structure. This efficiency-seeking versus the creative- seeking behaviour has been classified in the literature as the centralisation versus decentralisation debate. We argue that the two elements do not necessarily cancel each other out but coexist and evolve within the GIS model.

In this paper we tested in a representative sample of the world's top 100 food and beverage multinationals the application of a GIS model by bringing forward the existence of Technology Affiliates (TAs) and further more by discerning between two variants of TAs that reflect two broad knowledge generation activity i.e. adaptation and genuine forms of knowledge creation.

Our data show that the most important reason determining the presence of a large number of TAs is the country spread of the MNE. In other words, highly internationalised firms need to organise their R\&D activities through specialised affiliates which centralise and direct the innovative activities of the company. Most of these technological affiliates are located in the US, and to a lesser extent in Japan and a few European countries, confirming our arguments on specialised NSIs.

As already indicated, in order to capture the distinction among the various types of TAs, and to further analyse the relationship between the level of internationalisation of the company and the number of its technological affiliates the root node (TA) is split forming two new nodes: the first includes the technological affiliates involved in product adaptation (ADAPT). These include the SL1 and SL2 types of laboratories and the second, the rest of the technological affiliates, 
which are devoted to more creative forms of technological activity, e.g. basic research, etc. (OTHERTECH) which include the IIL and LIL types of laboratories. The large number of countries only remained as a determining predictor for the genuine creative overseas $R \& D$ units i.e. OTHERTECH.

In concluding, within an MNE a GIS secures access to new knowledge, its operationalisation in new goods and the prolonged competitiveness of these goods in globalized markets. Future research should focus in more detail on the dimensions of NSI that influence the dynamic evolution of GIS. In addition, we should look into the organizational challenges that dynamic element, i.e. decentralized knowledge creation of the GIS, poses to the MNE.

\section{References}

Alfranca O, Rama R, von Tunzelmann N. 2002. A patent analysis of global food and beverage firms: the persistence of innovation. Agribusiness An International Journal 18(3).

Alfranca O, Rama R, von Tunzelmann N. 2003. Competitive behaviour, design and technical innovation in food and beverage multinationals. IntJBiotechnology Special issue on "Innovation in Agriculture, Food and Beverages, and Biotechnology" , co-edition with IJTM.5:222-248.

Alfranca O, Rama R, von Tunzelmann N. 2004a. Combining different brands of in-house knowledge: technological capabilities in food, biotechnology, chemicals and drugs in agrifood multinationals. Science and Public Policy 31:227-244.

Alfranca O, Rama R, von Tunzelmann N. 2004b. Innovation spells in the multinational agrifood sector. Technovation 24:599-614.

Alfranca O, Rama R, von Tunzelmann N. 2005. Innovation in food and beverage multinationals. In: Rama R, editor. Multinational agribusinesses. New York and London: Haworth Press Inc.

Anastassopoulos G, Rama R. 2005. The Performance of Multinational Agribusinesses: Effects of Product and Geographical Diversification. In: Rama R, editor. Multinational agribusinesses. New York and London: Haworth Press Inc. p 73-113.

Archibugi D, Michie J. 1995. The globalisation of technology: a new taxonomy. Cambridge Journal of Economics 19:121-140.

Archibugi D, Pianta M. 1992. Specialization and size of technological activities in industrial countries: The analysis of patent data. Research Policy 21:79-93.

Bijman WB, van Tulder R, van Vliet M. Internationalisation of Dutch Agribusiness and the Organisation of R\&D; 1997; Seminar on Globalization of the Food Industry:, University of Reading, Reading. p 10.

Blanc H, Sierra C. 1999. The internationalisation of R\&D by multinationals: a trade-off between external and internal proximity. Cambridge Journal of Economics 23:187-206.

Cantwell J, Hodson C. 1991. Global R\&D and UK competitiveness. In: Casson M, editor. Global Research Strategy and International Competitiveness. Oxford and Cambridge: Basil Blackwell. p 133-183. 
Cantwell J, Janne O. 1999. Technological globalization and innovative centres: the role of corporate technological leadership and locational hierarchy. Research Policy 28(2-3):119144.

Cantwell J, Janne O. 2000. Globalization of innovatory capacity: the structure of competence accumulation in European home and host countries. In: Chesnais F, Ietto-Gillies G, Simonetti R, editors. European integration and global corporate strategies. London-NY: Routledge.

Cantwell J, Kosmopoulou E. 2001. Determinants of internationalisation of corporate technology. DRUID Working Papers. p 35.

Cohen WM, Levinthal DA. 1989. Innovation and learning: The two faces of R\&D. Economic Journal 99:569-596.

Connor JM. 1994. North America as a precursor of changes in Western European food-purchasing patterns. European Review of Agricultural Economics 21(2):1-173.

Chataway J. 2001. Novartis: New Agribusiness Strategy. AgroBioForum 4(1):14-19.

Christensen JF. 1998. The dynamics of the diversified corporation and the roles of central management of technology. DRUID Working Papers. p 47.

Christensen JL, Rama R, von Tunzelmann N. 1996. Study on innovation in the European Food Products and Beverages Industry. EIMS/SPRINT Brussels: The European Commission. Report nr EIMS SPRINT. 145 p.

Doz YL. 2005. A commentary on innovation systems in small open economies in light of the Sweedish, Israeli, Finnish and Singaporean experiences. In: Larédo P, Sachwald F, editors. Le système français d'innovation dans l'économie mondiale: enjeux et priorités. Paris: IFRIInstitut de l'Entreprise. p 101-105.

Erken H, Gilsing V. 2005. Relocation of R\&D - a Dutch perspective. Technovation 25:1079-1092.

Filippaios F, Rama R. Geographic patterns and cultural distance. The affiliates of the world's largest food and beverage MNEs. In: 32 EEIBA, editor; 2006; Fribourg, Switzerland p38.

Florida R. 1997. The globalisation of R\&D: Results of a survey of foreign-affiliated R\&D laboratories in the USA. Research Policy 26:85-103.

Frankho LG. 1989. Global corporate competition: Who's winning, who's losing, and the R\&D factor as one reason why. Strategic Management Journal 10:449-474.

G.E.S.T. 1986. Grappes technologiques. Les nouvelles stratégies d'entreprise. Paris: McGraw-Hill. $223 \mathrm{p}$.

Gassmann O, von Zedtwitz M. 1998. Organization of industrial R\&D on a global scale. R\&D Management 28(3):147-161.

Gerybadze A, Reger G. 1999. Globalization of R\&D: recent changes in the management of innovation in transnational corporations. Research Policy 28:251-274.

Granstrand O, Hakansson H, Sjölander S. 1993. Internationalization of R\&D- a survey of some recent research. Research Policy 22:413-430.

Hakanson L, Nobel R. 1993. Determinants of foreign R\&D in Sweedish multinationals. Research Policy 22:397-411.

Hu Y-S. 1992. Global or Stateless Corporations Are National Firms with International Operations. California Management Review 34(Winter):107-126.

IAMM. 1990. Les 100 premiers groupes agro-alimentaires mondiaux. Montpellier (France): AGRODATA Réseau Agropolis Stratégies. 85 p.

Ietto-Gillies G. 2002. Transnational Corporations. Fragmentation amidst Integration. London and N.Y.: Routledge. 
Kuemmerle W. 1997. All foreign R\&D sites fall into one of two cateories, and each type has different needs. Building effective $R \& D$ capabilities abroad. Harvard Business Review(March-April):61-70.

Kuemmerle W. 1999. Foreign direct investment in industrial research in the pharmaceutical and electronics industries- results from a survey of multinationals. Research Policy 28:179-193.

Lam A. 2003. Organisational learning in multinationals: R\&D networks of Japanese and US MNEs in the UK. Journal of Management Studies 40(3):673-703.

Le Bas C, Sierra C. 2002. 'Location versus home country advantages' in R\&D activities: some further results on multinationals' locational strategies. Research Policy 31:589-609.

Manolopoulos D, Papanastassiou M, Pearce R. 2005. Technology sourcing in multinational enterprises and the roles of subsidiaries: An empirical investigation. International Business Review 14:249-267.

OECD. 2005. Background report. Internationalisation of R\&D: Trends, issues and implications for S\&T policies. A review of the literature. Brussels: OECD Forum on the Internationalisation of R\&D. 1-67 p.

Padilla M, Laval GG, Allaya M-C, Allaya M. 1983. Les cent premiers groupes Agro-Industriels Mondiaux. Montpellier (France): IAMM.

Patel P, Pavitt K. 1991. Large firms in the production of the world's technology: an important case of 'non-globalisation. Journal of International Business Studies 22:1-21.

Pavitt K. 1992. Some foundations for a theory of the large innovating firm. In: Dosi G, Giannetti R, Toninelli PA, editors. Techonology and enterprise in a historical perspective: Clarendon Press Oxford.

Pearce R. 1995. Creative Subsidiaries and the Evolution of Technology in MNE. Discussion Papers in International Investment \& Business Studies. University of Reading: Discussion papers. p 29.

Pearce R. 1999. Decentralised R\&D and strategic competitiveness: globalised approaches to generation and use of technology in multinational enterprises (MNEs). Research Policy 28:157-178.

Pearce R, Papanastassiou M. 1999. Overseas R\&D and the strategic evolution of MNEs: evidence from laboratories in the UK. Research Policy 28:23-41.

Pearce RD. 1993. The growth and evolution of multinational enterprise. patterns of geographical and industrial diversification. Buckley PJ, editor. Cambridge (UK): Edward Elgar.

Rama R. 1996. Les multinationales et l'innovation. Localisation des activités technologiques de l'agro-alimentaire. Economie Rurale Paris 231(Janvier-Février):62-68.

Rastoin J-L, Tozanli S. Géostratégies des firmes agroalimentaires. In: Rastoin J-L, editor; 1998; Montpellier (France). AGRO-INRA. p 51-67.

Rastoin JL, Ghersi G, Pérez R, Tozanli S. 1998. Structures, performances et stratégies des groupes agro-alimentaires multinationaux. Montpellier: AGRODATA.

Reddy P. 2000. Globalization of R\&D. Implications for innovation systems in host countries. London \& New York: Routledge. 202 p.

Reger G. 2004. Coordinating globally dispersed research centres of excellence -- the case of Philips Electronics. Journal of International Management 10:51-76.

Rosenberg N. 1982. Inside the Black Box: Technology and Economics. Press CU, editor. Cambridge.

Sachwald F. 2005. Mondialisation et attractivité de la France pour la R\&D des entreprises. In: Larédo P, Sachwald F, editors. Le système français d'innovation dans l'économie mondiale: enjeux et priorités. Paris: IFRI-Institut de l'Entreprise. 
Schmidhuber J, Traill WB. 2006. Features of the Atlantic diet and its healthiness: theory and evidence from social science. EJEAFCHE (Electronic Journal of Environmental, Agriculture and Food Chemistry): EJEAFCHE. p 1-21.

Senker J, Mangematin V. 2007 Biotech innovation in Europe's food and drink processing industry: promise, barriers and exploitation. In: Rama R, editor. Handbook of innovation in the food and drink industry. New York, London and Oxford: Haworth Press Inc. forthcoming.

Stopford JM, Dunning JH. 1983. Multinationals. Company performance and global trends. London: McMillan Publishers.

Tozanli S. 2005. The rise of global enterprises in the world's food chain. In: Rama R, editor. Multinational Agribusinesses. N.Y.: Haworth Press Inc.

UNCTAD. 2005. Wold Investment Report 2005. Transnational corporations and the internationalization of R\&D. New York and Geneva: United Nations. 331 p.

von Tunzelmann GN. 1998. Localized technological search and multi-technology companies. Economics of Innovation and New Technology 6:231-255.

von Tunzelmann GN, Acha V. 2005. Innovation in 'low-tech' industries. In: Fagerberg J, Mowery D, Nelson R, editors. The Oxford Handbook of Innovation. New York, Oxford: Oxford University Press. p 407-432.

von Zedtwitz M, Gassmann O, Boutellier R. 2004. Organizing global R\&D, challenges and dilemmas. Journal of International Management 10:21-49.

Wilkinson J. 2002. The final foods industry and the changing of the global agro-food system. Sociologia Ruralis 42(4):329-346.

Wortmann M. 1990. Multinationals and the internationalization of R\&D: New developments in German companies. Research Policy 19(2):175-183. 